\title{
Recent developments in Corporate Taxation in Sweden*
}

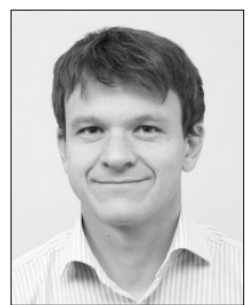

Christian Thomann

CESIS - Centre of Excellence for

Science and Innivation Studies,

Royal Institute of Tecnology

\begin{abstract}
This article investigates if increasing neutrality between debt and equity capital might improve the efficiency in a corporate tax system. Firm-level and sector-level taxation data from Sweden is used to study if a tax system that is characterized by very few limitations with respect to the deductibility of interest costs leads to systematic differences in the taxes paid by different sectors. This paper finds that there are differences between different sectors' tax payments and these differences can be explained by the sectors' use of debt capital.
\end{abstract}

JEL Classification: D58, H25

Keywords: Tax Reform, Corporate Tax, Debt, Equity.

\section{Introduction}

During the last few years the corporate tax which is considered to be one of the most harmful taxes for economic growth has received con-

* The author thanks Axel Hilling (the editor), Per Classon, Rickard Eriksson, Linda Haggren, Andreas Högberg, David Kleist, Gustav Martinsson, Mikael Riis Jacobsen, Razvan Pascalau, Elisabeth Sheik and, especially, Bo Stoltz and the participants of the annual conference of the Nordic Tax Research Council in Oslo, Norway. All errors and omissions are my own. This paper was written in my capacity as a researcher at CESIS and the views expressed and all remaining errors are solely the responsibility of the author. 
siderable attention on both national and international levels. ${ }^{1}$ Sweden is no exception. Here corporate income tax rates were cut in 2009 (from 28 per cent and 26.3 per cent) and 2013 (to 22 per cent). Both rate cuts were accompanied by base broadening measures. In addition to these rate cuts, in 2011, the Swedish Government instituted a Committee on Corporate Income Taxation. In its proposal dating June $12^{\text {th }}$ 2014 the Committee suggests to introduce a new corporate tax system. ${ }^{2}$ The proposal aims to reduce the tax burden on risk capital and to increase neutrality between the taxation of debt and equity capital. At the moment, the Swedish tax system's treatment of debt and equity is non-neutral as it, like many other tax systems, favors debt finance over equity finance. It allows costs associated with debt finance to be deducted against taxable profits. Costs associated with equity capital must be paid from after-tax income.The proposal suggests to broaden the corporate tax base by, among others, abolishing the possibility to deduct net financial costs from taxable profits. The proposal suggests that broadening the tax base in such a manner allows to introduce a financing allowance that lowers the effective formal corporate tax rate by 5.5 per centage points (from 22 per cent to 16.5 per cent).

Other examples where the corporate income tax has received some considerable attention from academics and legislators are, among others, the United Kingdom and Norway. In the United Kingdom the report Tax by Design: the Mirrlees Review (2010) proposed a tax reform where the corporate income tax was considered one of the key taxes to increase economic growth. Notably the corporate income tax reform suggested by Mirrlees (2010) was to narrow the difference in the tax treatment of debt and equity capital. In Norway a tax commission appointed by the government is to deliver a reform proposal in the fall of 2014. ${ }^{3}$ Moreover, the OECD has issued an action plan to address the challenges that the present corporate income tax system faces as a result of increasing internationalization of production processes and the increasing importance of the digital economy. Both give corporations possibilities to shift corporate income from high tax ju-

1 There exists some considerable literature eg Lee and Gordon (2005), OECD (2010) and Johansson et al. (2008) underscoring that the corporate income tax is one of the most harmful taxes for economic growth.

2 The administration is not bound by the proposal. It may decide to proceed with the proposal or to discard it. Directive (2011) contains the administration's instruction to the Committee. FSK (2014) provides for a summary of the propsals (in English).

3. http://www.regjeringen.no/en/archive/Stoltenbergs-2nd-Government/ ministry-of-Finance/Nyheter-og-pressemeldinger/pressemeldinger/ 2013/nytt-offentlig-skatteutvalg/mandate-of-the-tax-commission.html?id $=717833$ 
risdictions to low tax jurisdictions (OECD, 2013). On the European level the European Commission has presented a proposal for a Common Consolidated Corporate Tax Base (CCCTB). ${ }^{4}$ The CCCTB would present an alternative to the present tax system that builds upon the arms-length principle and which taxes profits at source. The CССТВ proposal suggests that a corporation's total taxable profits would be added up on the EU-level before the tax base is to be allocated according to a formulary apportionment.

The recent cut in the corporate inome tax rate in Sweden was accompanied by new legislation that limits the tax deductibility of interest expenses to related parties. ${ }^{5}$ The legislative action is motivated by stating that it is necessary to strengthen the business climate in Sweden, to ensure that Sweden is attractive for national and international investments and that the Swedish corporate tax base needs to be protected against aggressive tax planning (Budgetpropositionen, 2013). The latter point was raised, among others, by a public report prepared by the Swedish tax agency (Skatteverket, 2012). These reports showed that the Swedish tax base was suffering from extensive profit shifting by firms abusing the tax deductibility of internal interest payments to related parties located in low tax jurisdictions. The budget bill states that the limits regarding interest deductions are expected to raise SEK 8.8 bn (Budget, 2013).

Motivated by the international attention that the corporate income tax and in particular the treatment of debt and equity capital has received this article reviews the arguments and measures proposed for increasing neutrality between debt and equity capital and how this might improve the efficiency of a corporate income tax system. ${ }^{6}$ There are a number of studies on the tax treatment of debt and equity capital in Sweden e.g. King and Fullerton (1984), Agell et al. (1998), Lindhe et al (2004), Sørensen (2008), and Sørensen (2010). All of these studies find that there are considerable differences in the marginal tax rates for investments that are financed with equity or debt. Södersten (2014) suggests that the effective marginal tax rate for debt financed investments is negative (-18.3 per cent) while it is positive ( 20 per cent) for equity financed investments. Given such differences in marginal tax rates one would expect all firms to always finance their marginal investments with debt capital. However, there are both costs and benefits associated with debt. On the one hand, a higher level of debt may lead to costs of financial distress (eg bankruptcy costs). On the other

\section{EU (2011).}

Kleist (2014) provides for a brief description of these rules.

6 Anderssson el al (2013) investigate how a reform aiming at reducing the beneficial treatment of debt capital in Sweden might look like. 
hand, debt may discipline managers and reduce owners' monitoring costs. As a result, firms will tend to balance the benefits and the costs of debt. In addition, the debt capacity may vary between different companies and/or sectors depending on the technology used in production. In general, firms that have more real assets might be able to take on more debt. Also older firms might be able to obtain bank loans easier than younger firms.

According to the literature differences in the treatment of debt and equity capital are likely to lead to inefficient allocation of resources and to welfare losses. On the one hand, the favorable treatment of debt financed investments, reflected e.g. in the negative marginal effective tax rates, leads to an inefficient mix of investments. There are too many investments that yield low returns that are financed with debt. On the other hand, due to the positive positive marginal tax rate on investments financed with equity there are too few equity financed investments. Such an allocation violates the production efficiency theorem of Diamond and Mirrlees (1973). ${ }^{7}$ Sørensen (2010) estimates that the efficiency loss due to the inefficient investment mix to be approximately SEK $7.2 \mathrm{bn}$, or approximately 8.7 per cent of the corporate taxes paid by widely held corporations in Sweden. Second, the favorable tax treatment of debt induces firms to increase their leverage. In particular, Sørensen suggests that differences in the tax treatment of debt and equity lead firms to increase their leverage to suboptimal levels. Indeed, De Mooij and Ederveen (2008) suggest that a one per centage point increase in the corporate tax rate increases the leverage of a representative firm by about 0.3 per centage points. Translated to the Swedish corporate tax rate of 22 per cent this means that Swedish firms' debt is 6.6 per centage points higher, than it would be in a completely neutral system, due to the corporate tax. On the other hand, an increase in leverage increases the probability that a firm experiences financial distress. It is well documented that financial distress is costly. ${ }^{8}$ Sørensen (2010) estimates the costs of financial distress to around SEK $21.4 \mathrm{bn} .{ }^{9}$ In addition, there exists a considerable literature suggesting that higher levels of debt finance may increase the amplitude of the business cycle. ${ }^{10}$

7 Diamond and Mirrlees (1973) show that an efficient tax system does not interfere with firms' and individuals' investment and financing decisions.

8 An example is Almeida and Philippon (2007) and Graham (2000).

9 This equals approximately 0,6 per cent of GDP in 2010 or around 20 per cent of corporate tax payments for the same year.

10 Some examples are Bernanke, Gertler och Gilchrist (1996, 1999). Berg, Hansen och Sehlin (2004) discuss the implications for Sweden. Brown et al. (2012) provide for insights how the financial accelerator may impact the financing of research and development. 
The literature presented above suggests that the asymmetric treatment of debt and equity capital is likely to distort financing and investment decisions. However, many findings presented in the literature are derived using abstract theoretical models. This article investigates if some of the effects prescribed in the theoretical literature, e.g. relatively lower tax payments of sectors that have high leverage, can be found in sector level data.

Some statistics are shown below but in general there seems to be differences in the taxes paid by different sectors and these differences could, according to the literature, be the result of the different sectors' ability to finance their investments with debt capital. In addition to these findings we also present a brief summary of the structure of the Swedish corporate tax receipts. The data exhibits patterns that are in line with the theoretical results of Sørensen (2010) and Mirrlees (2011) who suggest that the present tax system which basically allows for all interest costs to be deducted from a corporation's taxable income leads to considerable distortions. ${ }^{11}$ Sørensen states that a tax reform that aims at aligning the tax treatment of debt and equity capital is likely to increase efficiency. A corporate tax system that is more neutral in its treatment of debt and equity capital is to allow corporations to deduct a calculated return on the equity invested in the business. This deduction, which is usually referred to as an allowance for corporate equity (ACE), parallels the deduction allowed for interest paid on a business' debt capital. Another possibility is to eliminate the favorable treatment of debt financed investments by disallowing corporations to deduct interest expenses. This is usually referred to as Comprehensive Business Income Tax - CBIT. The proposal by the Swedish Committee on Corporate Income Taxation can be classified as a CBIT system (FSK, 2014).

This article proceeds in the following manner. Section 2 presents a general overview over corporate income tax receipts and different measures of corporate tax rates in Sweden. Section 3 presents the data. Section 4 analyzes if there are systematic differences between different sectors corporate income tax payments. Section 5 concludes.

\section{Corporate Tax Rates and Revenue}

In 1991 a major reform of the Swedish tax system was instituted. ${ }^{12}$ The reform termed tax reform of the century applied the strategy of rate

11 Since 2013 and 2009 there are restrictions on the possibilities to deduct interest payments to related parties (Budget 2013).

12 The reform is described in, among others, Lodin (2011). 
cuts and base broadening in an "unusually thorough manner" (Agell et al. 1998). It introduced a dual income tax system where capital income is subject to a proportional tax while labor income is subject to a progressive income tax. The reform set the corporate tax rate at 30 per cent. In difference to the corporate tax system before the reform, the new tax system applied a single rate and offered very few tax credits. ${ }^{13}$ The corporate tax rate was lowered in 1994 to 28 per cent and thereafter in 2009, to 26.3 per cent and, more recently, in 2013, to 22 per cent. Figure 1 presents the Swedish corporate tax rate and the mean corporate tax rate for OECD member countries and the EU27. Figure 1 shows that until 2003 the nominal Swedish corporate tax rate was lower than the mean tax rate for the EU and until 2005 for the OECD countries. As late as 2012 the Swedish corporate tax rate was higher than the OECD average (23.2 per cent) and EU average (23.5).

Looking at the revenues from the corporate income tax we find that these were on average around 3.0 per cent of GDP over the period 1995-2010. This is very close to the arithmetic mean of the EU27 countries. Figure 2 also underscores that corporate income tax revenues are, at least on the country level, rather volatile. Between 2000 and 2002 the corporate tax revenues decreased by nearly 50 per cent. One reason for why corporate tax revenues have decreased at a slower pace than tax rates is that many countries have combined changes in the corporate tax rate and base broadening measures. This holds, as stated in Section 1, even for Sweden. The rate cuts in 2009 and 2013 were both accompanied by measures limiting corporations' interest deductions for loans to internal parties. Another possible explanation to the relative stable path of corporate tax revenues is that the economy has been more incorporated, i.e. the corporate sectors share of the total economy has increased.

13 The only significant deviations, besides the differences in the treatment of debt and equity capital, stem from the principle of neutrality that can be found in the Swedish corporate tax system are the rather generous depreciation schedule and the "periodiseringsfond". 


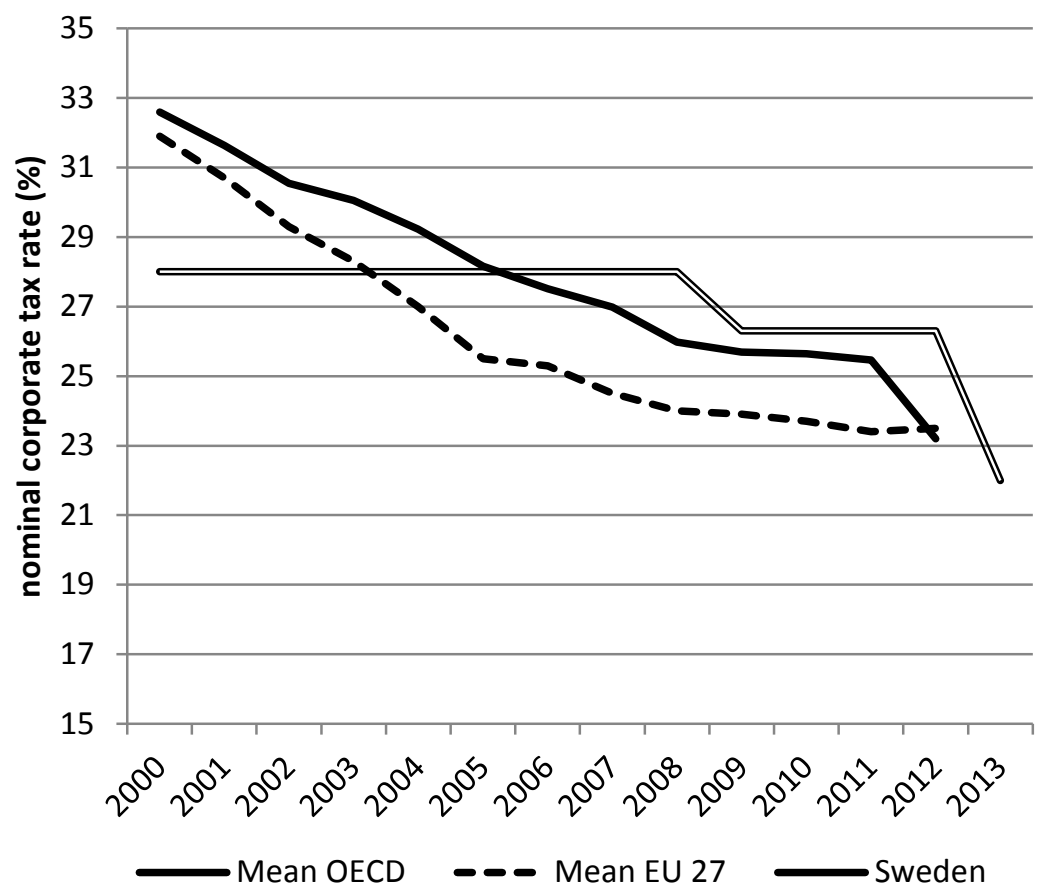

Figure 1 Corporate Tax Rates, Sweden, EU and OECD 2000-2013 (Data: OECD Tax Database och European Commission (2013) Taxation Trends in the European Union)

Figure 1 presents the formal corporate tax rates for Sweden and the arithmetic mean of the formal tax rates for all OECD countries and all EU countries. 


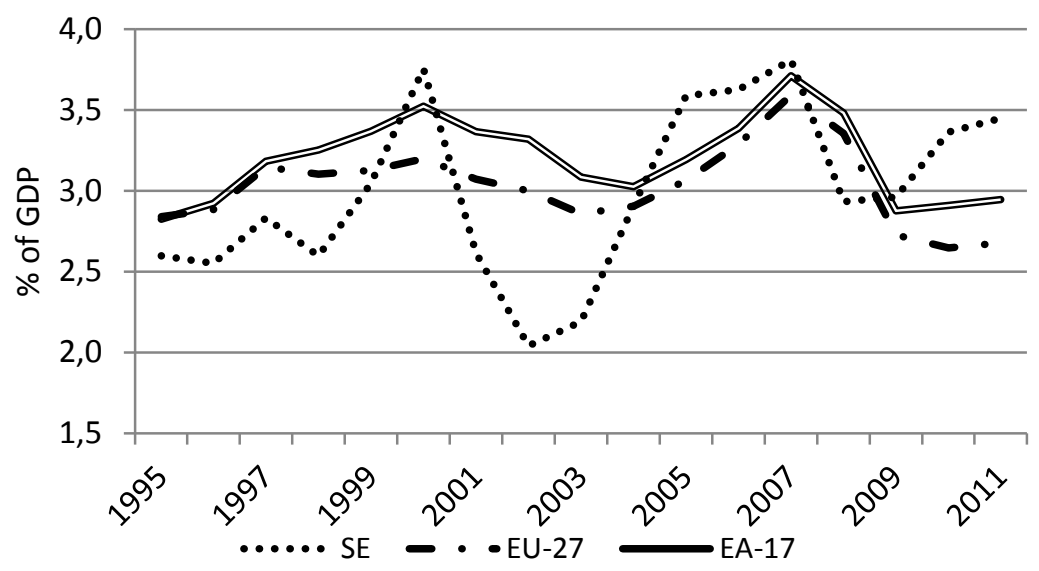

Figure 2 Corporate income tax revenues 1995-2011, measures as per cent of BDP. Sweden, Euro-members (EA-17) and EU countries (EU 27), Source: European Commission (2013) Taxation Trends in the European Union

Figure 2 presents corporate income tax receipts as per cent of GDP. EU27 (EA17) denotes the arithmetic mean of the formal corporate income tax rates for the $27 \mathrm{EU}$ member states and the 17 member states of the Euro area

\section{Data}

This study uses comprehensive firm-level data on corporations' tax filings in Sweden. The data is from the Swedish tax revenue service and it spans from 2007 to 2011. We obtain the anonymized data through Statistics Sweden (SCB). Sweden employs a system where all firms incorporated in Sweden have a unique identifier. The data covers all firms incorporated as limited liability stock corporations in Sweden. The data is unconsolidated. ${ }^{14}$ For 2011 there are about 300 thousand of such firms. The data contains information on both firms' balance sheets and profit and loss statements. In addition, we also have, among others, information on firms' sector. While taxation in Sweden is done on a firm level firms are able to consolidate their profits and losses for tax purposes. As a result the domestic parts of corporate groups are treated as a single firm in terms of taxes. To be able to transfer losses or profits across group members firms must own di-

14 Firms belonging to corporate groups use an "equity" method (Rajan and Zingales, 1995) to account for an affiliate's net assets. Under this method, these net assets are shown as investments in the parent firm's balance sheet. 
rectly or indirectly more than 90 per cent of its related parties' shares. In order to reflect this possibility, we need to consolidate our data for some parts of our analysis into corporate groups. Data on corporate groups is provided by the Swedish corporation office (Bolagsverket). Consolidating firms into corporate groups also has the advantage that this will better reflect the fact that profitability, in a group taxation system, will likely depend on the groups' profitability rather than the profitability of an individual firm. ${ }^{15}$ To investigate the sector-specific differences between firms we use the industry classifications assigned by SCB to categorize our firms into 20 broad sectors. Table 1 presents an overview over the classification of firms.

Table 1 Classification of Sectors

\begin{tabular}{lll}
\hline sector_name & Swedish Standard Classification & \\
\hline agriculture & Agriculture, forestry and fishing & $\mathrm{A}$ \\
communciation & Information and communication & $\mathrm{J}$ \\
construction & Construction & $\mathrm{F}$ \\
culture & Arts, entertainment and recreation & $\mathrm{R}$ \\
education & Education & $\mathrm{P}$ \\
finance & Financial and insurance activities & $\mathrm{K}$ \\
gas prod & Electricity, gas, steam and air conditioning sup- & $\mathrm{D}$ \\
& ply & \\
health & Human health and social work activities & $\mathrm{Q}$ \\
hotel restaurant & Accommodation and food service activities & $\mathrm{I}$ \\
lacks sector & . & \\
law econ research & Professional, scientific and technical activities & $\mathrm{M}$ \\
manufacturing & Manufacturing & $\mathrm{C}$ \\
minerals & Mining and quarrying & $\mathrm{B}$ \\
public sector & Public administration and defence; compulsory & $\mathrm{O}$ \\
& social security & \\
real estate & Real estate activities & $\mathrm{L}$ \\
rental aso & Administrative and support service activities & $\mathrm{N}$ \\
service computers & Other service activities & $\mathrm{S}$ \\
trade sales & Wholesale and retail trade; repair of motor ve- & $\mathrm{G}$ \\
hransport & hicles and motorcycles & \\
Water & Transportation and storage & $\mathrm{H}$ \\
& Water supply; sewerage, waste management & $\mathrm{E}$ \\
\hline Data from Statistics Sweden & and remediation activities & \\
\hline
\end{tabular}

15 When aggregating firms into corporate groups we add up balance sheet and profit and loss statements across different firms that belong to a specific corporate group. Given that a corporate group can only belong to a single industry and that a corporate group can only have a single date of incorporation we allow the firm that has the largest number of employees to determine the group's industry classification. 
Table 2 shows the number of firms by sector. The consolidation procedure leaves us with 228 thousand observations for 2007. This number grows to 304 thousand observations in 2011. The sector that in 2011 has the largest number of firms is law econ research (62 thousand). It is followed by trade sales (56 thousand) and construction (34 thousand). Among these three groups we find that the number of firms grows by around $40 \%$ for both law econ research (plus $44 \%$ ) and construction (40\%). The increase in the number of firms that belong to trade sales is considerably lower (plus $19 \%$ ). The last row shows simple concentration ratios with respect to the corporate income tax. Here we find that, on average, about $56 \%$ of all firms pay corporate tax. We find that there is some variation in this number. In 2007 there are $60 \%$ of firms paying corporate tax, for 2009 this number is equal to $52 \%$ and $54 \%$ in 2011.

Table 2 Number of firms 2007-2011 (thousands), source, SCB FRIDA dabase

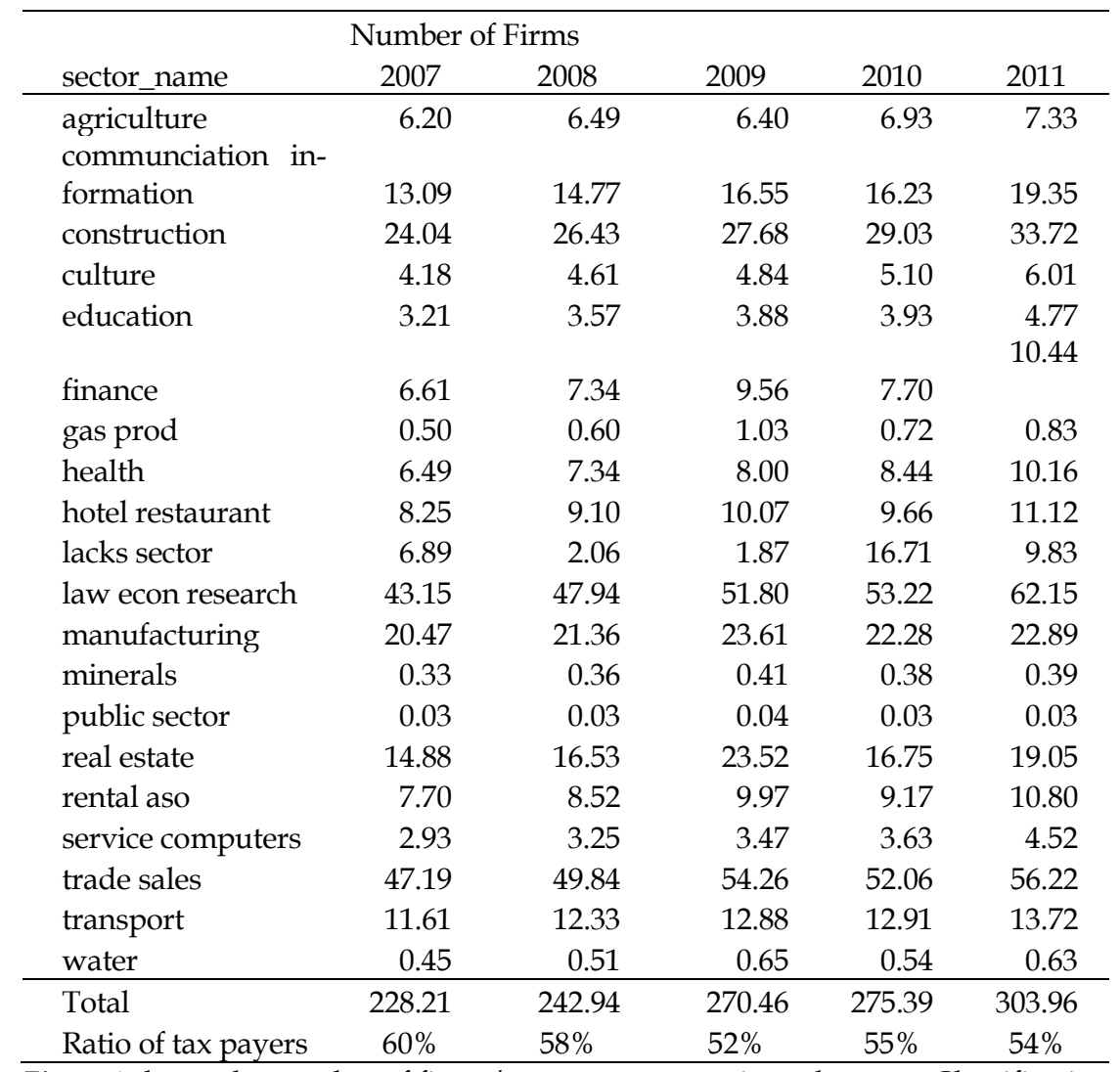

Figure 1 shows the number of firms/corporate groups in each sector. Classification from statistics Sweden. Ratio of tax payers shows the ratio of firms that pays more than sek 1000 in corporate income tax. Consolidated data.

204 Christian Thomann 
Table 3 uses data from SCB to present information on sectors' employment. The largest sectors by employment are manufacturing $21 \%$ of all employment in the corporate sector, followed by trade sales $(18 \%)$ and construction $(10 \%)$. This table also shows that all sectors increase employment with the exception of manufacturing. Between 2007 and 2011 we find that total employment grows from 2.51 million to 2.67 million. This is an increase by $6 \%$.

Table 3 Employment in the corporate sector

\begin{tabular}{|c|c|c|c|c|c|c|}
\hline & \multicolumn{5}{|c|}{ Employment (\% of corporate sector) } & \multirow{2}{*}{$\begin{array}{c}\text { Employ } \\
\text { ment } \\
\text { Growth }\end{array}$} \\
\hline & 2007 & 2008 & 2009 & 2010 & 2011 & \\
\hline $\begin{array}{l}\text { agriculture } \\
\text { communciation }\end{array}$ & $1 \%$ & $1 \%$ & $1 \%$ & $2 \%$ & $2 \%$ & $17 \%$ \\
\hline infor & $6 \%$ & $6 \%$ & $6 \%$ & $6 \%$ & $6 \%$ & $4 \%$ \\
\hline construction & $9 \%$ & $9 \%$ & $10 \%$ & $10 \%$ & $10 \%$ & $17 \%$ \\
\hline culture & $1 \%$ & $1 \%$ & $1 \%$ & $1 \%$ & $1 \%$ & $16 \%$ \\
\hline education & $2 \%$ & $2 \%$ & $2 \%$ & $2 \%$ & $2 \%$ & $44 \%$ \\
\hline finance & $3 \%$ & $3 \%$ & $3 \%$ & $3 \%$ & $3 \%$ & $5 \%$ \\
\hline gas prod & $1 \%$ & $1 \%$ & $1 \%$ & $1 \%$ & $1 \%$ & $2 \%$ \\
\hline health & $4 \%$ & $4 \%$ & $5 \%$ & $5 \%$ & $6 \%$ & $45 \%$ \\
\hline $\begin{array}{l}\text { hotel restaurant } \\
\text { lacks sector }\end{array}$ & $4 \%$ & $4 \%$ & $4 \%$ & $4 \%$ & $4 \%$ & $21 \%$ \\
\hline $\begin{array}{l}\text { law econ re- } \\
\text { search }\end{array}$ & $7 \%$ & $8 \%$ & $8 \%$ & $8 \%$ & $8 \%$ & $15 \%$ \\
\hline manufacturing & $25 \%$ & $24 \%$ & $22 \%$ & $21 \%$ & $21 \%$ & $-13 \%$ \\
\hline $\begin{array}{l}\text { minerals } \\
\text { public sector }\end{array}$ & $0 \%$ & $0 \%$ & $0 \%$ & $0 \%$ & $0 \%$ & $10 \%$ \\
\hline real estate & $2 \%$ & $2 \%$ & $2 \%$ & $2 \%$ & $2 \%$ & $6 \%$ \\
\hline $\begin{array}{l}\text { rental aso } \\
\text { service comput- }\end{array}$ & $6 \%$ & $7 \%$ & $7 \%$ & $7 \%$ & $7 \%$ & $27 \%$ \\
\hline ers & $1 \%$ & $1 \%$ & $1 \%$ & $1 \%$ & $1 \%$ & $23 \%$ \\
\hline trade sales & $18 \%$ & $18 \%$ & $18 \%$ & $18 \%$ & $18 \%$ & $3 \%$ \\
\hline transport & $8 \%$ & $8 \%$ & $8 \%$ & $8 \%$ & $8 \%$ & $1 \%$ \\
\hline water & $1 \%$ & $1 \%$ & $1 \%$ & $1 \%$ & $1 \%$ & $17 \%$ \\
\hline $\begin{array}{l}\text { Total Employ- } \\
\text { ment }(\mathrm{m})\end{array}$ & 2.51 & 2.59 & 2.53 & 2.56 & 2.67 & $6 \%$ \\
\hline
\end{tabular}

Data from SCB, Basfakta företag enligt Företagens ekonomi efter näringsgren SNI 2007. Finance from FRIDA database. We exclude the category public sector, which eg includes international organisations.

Table 4 presents the accumulated tax payments on a sector level.16 The four largest sectors are manufacturing (tax payments are between $27 \%$ and $22 \%$ of all corporate tax payments), trade sales (between $15 \%$

16 A similar table can be found in Wahlberg (2012). 
and 20\%), finance (between 9\% and 18\%) and construction (between 5 $\%$ and $11 \%$ ) Table 4 also presents the accumulated tax payments made by the 30 and 100 largest tax payers. We find that that 30 (100) largest tax payers pay about SEK 34.7 bn (SEK 50.7 bn) in corporate tax. Tax payments from the 30 largest employers amount, on average, to SEK $13 \mathrm{bn}$. However, due to the financial crisis this number exhibits large considerable variation. In 2008 the 30 largest firms in terms of employment paid only SEK 5.5 bn in corporate income tax. In 2011 this number was equal to SEK $21.9 \mathrm{bn}$.

Table 4 Corporate income tax payments by sector and size (fraction)

\begin{tabular}{|c|c|c|c|c|c|}
\hline $\begin{array}{l}\text { Corporate income tax } \\
\text { payments by sector (frac- } \\
\text { tion of total corporate in- } \\
\text { come taxes paid in Swe- } \\
\text { den) }\end{array}$ & 2007 & 2008 & 2009 & 2010 & 2011 \\
\hline agriculture & $1 \%$ & $1 \%$ & $1 \%$ & $1 \%$ & $1 \%$ \\
\hline communciation infor & $6 \%$ & $4 \%$ & $4 \%$ & $7 \%$ & $5 \%$ \\
\hline construction & $6 \%$ & $11 \%$ & $5 \%$ & $10 \%$ & $10 \%$ \\
\hline culture & $0 \%$ & $0 \%$ & $0 \%$ & $0 \%$ & $1 \%$ \\
\hline education & $0 \%$ & $0 \%$ & $1 \%$ & $0 \%$ & $0 \%$ \\
\hline finance & $12 \%$ & $9 \%$ & $19 \%$ & $17 \%$ & $18 \%$ \\
\hline gas prod & $3 \%$ & $3 \%$ & $8 \%$ & $3 \%$ & $2 \%$ \\
\hline health & $1 \%$ & $2 \%$ & $1 \%$ & $2 \%$ & $1 \%$ \\
\hline hotel restaurant & $1 \%$ & $1 \%$ & $1 \%$ & $1 \%$ & $1 \%$ \\
\hline lacks sector & $1 \%$ & $0 \%$ & $0 \%$ & $1 \%$ & $0 \%$ \\
\hline law econ research & $11 \%$ & $9 \%$ & $10 \%$ & $6 \%$ & $7 \%$ \\
\hline manufacturing & $27 \%$ & $23 \%$ & $19 \%$ & $21 \%$ & $22 \%$ \\
\hline minerals & $2 \%$ & $3 \%$ & $0 \%$ & $4 \%$ & $4 \%$ \\
\hline public sector & $0 \%$ & $0 \%$ & $0 \%$ & $0 \%$ & $0 \%$ \\
\hline real estate & $5 \%$ & $6 \%$ & $6 \%$ & $5 \%$ & $3 \%$ \\
\hline rental aso & $2 \%$ & $3 \%$ & $6 \%$ & $2 \%$ & $2 \%$ \\
\hline service computers & $0 \%$ & $0 \%$ & $1 \%$ & $0 \%$ & $0 \%$ \\
\hline trade sales & $17 \%$ & $20 \%$ & $15 \%$ & $19 \%$ & $19 \%$ \\
\hline transport & $2 \%$ & $2 \%$ & $2 \%$ & $2 \%$ & $2 \%$ \\
\hline water & $1 \%$ & $0 \%$ & $0 \%$ & $0 \%$ & $0 \%$ \\
\hline Total (sek bn) & 95.7 & 74.6 & 84.1 & 104.2 & 100.1 \\
\hline $\begin{array}{l}\text { Tax payments: large } \\
\text { firms }\end{array}$ & & & & & \\
\hline Top 30 tax (sek bn) & 33.9 & 23.5 & 31.2 & 45 & 39.7 \\
\hline Top 100 tax (sek bn) & 46.1 & 30.9 & 39.9 & 57.5 & 50.7 \\
\hline Top 30 empl (sek bn) & 9.6 & 5.5 & 11 & 21.9 & 17.0 \\
\hline
\end{tabular}




\section{Analysis}

Section 4 investigates if there are systematic differences between sectors' tax payments and their income. It also studies how different sectors compare in their use of debt capital. Following standard finance textbooks, i.e. Bodie and Merton (2000), we proxy firm's income before taxes using a variable called ebit (earnings before interest and taxes). We use firms' tax filings to calculate the ebit measure. We obtain ebit as the difference between corporations' declared income and its interest payments. If ebit is negative we set ebit to zero. Table 5 presents ebit on a sector level. More precisely, column (1) shows each sector's mean fraction of the total ebit produced by the corporate sector in Sweden for 2007-2011. However, given that ebit is not meaningful measure for financial corporations we exclude these firms when providing statistics with regard to ebit. ${ }^{17}$ To allow for a comparison between ebit and tax payments we also provide each sector's fraction of total tax payments. Again, this ratio disregards the financial sector. Looking at column (1) we find that the largest sectors in terms of ebit are manufacturing $27.4 \%$, trade sales $18.3 \%$ and construction which stands for $9.1 \%$ of total ebit and real estate $9.5 \%$. Looking at these sectors' fractions of the total corporate tax payments which we present in column (2) we find that these are rather close to these sectors' fraction of total ebit. ${ }^{18}$ The main exception when looking at these four sectors is the real estate sector. Here, we find that this sector's tax payments are only equal to $5.8 \%$ of total tax payments. Below, we show that this difference can, to some extend, be explained by the sector's use of debt capital.

By looking at the ratio of a sector's tax payments and ebit, we refer to this ratio as tax/ebit, presented in column (3), we learn that there are considerable differences between the sectors. tax/ebit ${ }_{j}$ ranges from $12.6 \%$ (real estate) to $27.9 \%$ (service computers). We find that tax/ebit is greater than $20 \%$ for manufacturing $(20.5 \%)$, trade sales $(24.6 \%)$ and even construction (22.6\%). A possible interpretation of this finding is that the effective tax rate on ebit faced by a typical firm that belongs to sector $j$ differs considerably between sectors.

17 Eriksson and Högberg (2013) discuss financial sector taxation.

18 The numbers for manufacturing, trade sales and construction are: $26.6 \%$, $21.6 \%$ and $9.8 \%$. 
Given that interest payments are tax deductible we now investigate if the pattern observed above can be explained by looking at sectors' usage of debt and equity capital. Column (4) shows the median of sector $j$ 's leverage (ratio of debt to total assets) and column (5) the third quartile of leverage. ${ }^{19}$ Colum (4) presents what could be the leverage of a representative firm from a given sector. We see that there are some differences between the sectors. Leverage is highest for the real estate (median: 65\%), manufacturing (47\%), trade sales (46\%). Given that it is primarily fixed assets that allow companies to finance themselves with debt capital we investigate into SCB's corporate asset data. Here, we find that manufacturing is the largest, nearly $30 \%$ of all assets while real estate sector is second with $18.2 \%$ of all assets. Trade sales has considerably less fixed assets than would be expected from the sector's ebit. Indeed this sector which stands for $18.3 \%$ of all ebit has only $11.4 \%$ of all assets in the corporate sector.

19 We calculate debt following Rajan and Zingales (1995.

208 Christian Thomann 
Table 5 Sectors' fraction of EBIT, tax payments and total assets. and corporate income tax payments by sector: 2011

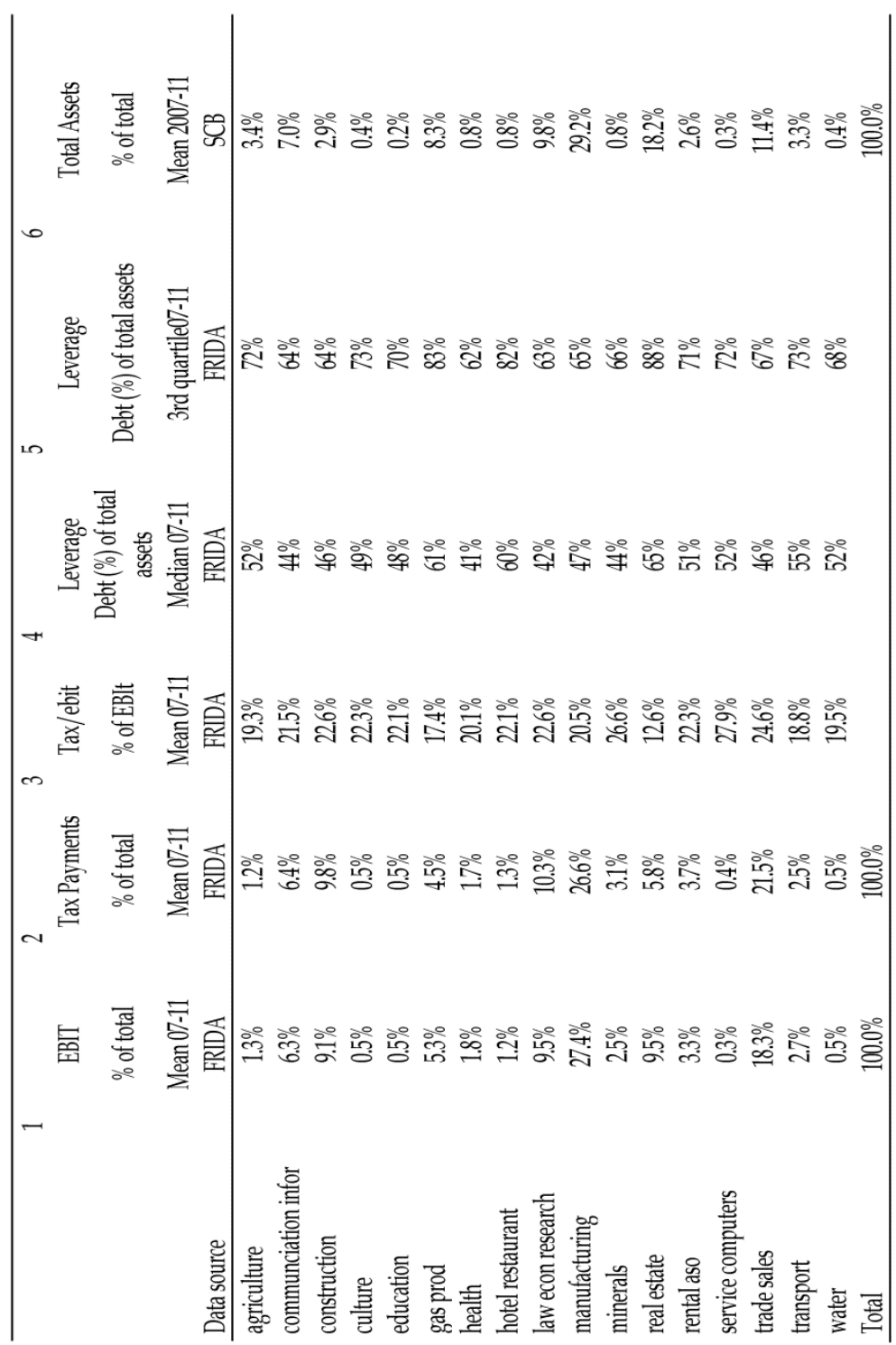

ebit is calculated by adding interest expenses to a firms' taxable result. Table shows sector's part part of total ebit for corporate sector. Table does not consider negative ebit. Tax_ebit is the ratio of corporate income tax payments to ebit. Data from the Swedish corporate database (FRIDA). Tables excludes financial sector as both interest income and interest expense are central for the sector's business model. Table also excludes public sector and firms that lack sector. 
Looking at the total of the corporate sector we learn that tax/ebit is on average $23.6 \%(2007), 19.8 \%$ (2008), 18.8\% (2009), 22.8\% (2010) and $20.2 \%$ (2011). ${ }^{20}$ The corporate tax rate was $28 \%$ until 2009 and $26.3 \%$ thereafter. Taken at face value, disregarding distributional and efficiency effects among sectors and without considering the effect of limits on the interest rate deductions introduced in 2013, a simple calculation suggests that this amounts to 6.1 per centage points of the corporate tax rate. In this example, the "value" of this fully deductible interest rate is 6.1 per centage points. ${ }^{21}$

The statics presented above suggest that there is a strong relation between a sector's ability to use debt capital and its corporate income tax payments. We now employ regression analysis to provide for an additional test. We use a unconsolidated subsample of the data presented in Table 5, namely data from the year 2011, to test whether a firm's use of debt capital can explain its tax payments. We use leverage to denote a firm's use of debt capital and tax_ebit to measure a firms's tax payments. We restrict our sample to non-financial firms. ${ }^{22}$ Firms also need to have one or more employees. Table 6 presents the data. There about 124 thousand firms in our sample. The mean of leverage $j$ is $38 \%$. The mean of tax_ebit is equal to $23 \%$.

Table 6 Firm-level data on leverage and tax/ebit, year 2011, nonconsolidated data (Source FRIDA)

\begin{tabular}{lcccc}
\hline & $\mathrm{N}$ & Mean & $\begin{array}{c}\text { Standard } \\
\text { Deviation }\end{array}$ & Median \\
\hline leverage & 123828 & 0.38 & 0.20 & 0.36 \\
Tax/ebit & 123828 & 0.23 & 0.09 & 0.26 \\
\hline Data from the Swedish corporate database (FRIDA). Tables excludes financial sector
\end{tabular}

Data from the Swedish corporate database (FRIDA). Tables excludes financial sector as both interest income and interest expense are central for the sector's business model. Table also excludes firms without any employees, public sector and firms that lack sector. ebit is calculated by adding interest expenses to a firms' taxable result. Table does not consider negative ebit. Tax_ebit is the ratio of corporate income tax payments to ebit.

We use the data presented in table to run the following amd very simple regression:

(1) Tax_ebitj $=c+\beta$ * leverage $j+\varepsilon j$

20 These measures are weighted by sectors' ebit and tax payments.

21 We would expect the revenue effect to be somewhat smaller when one considers the effect of the interest deduction limits introduced in 2013. Considering the caluculations made in Budgetpropositionen (2013) one might have to adjust the $6 \%$ to $4 \%$.

22 Furthermore, we delete observations where the ratio of tax/ebitj is greater than 1. 
Finding that the regression yields significant results would indicate that a firm's leverage can explain a its tax/ebit. Running our regression we obtain the following result:

(2) Tax_ebitj $=0.30^{* * *}-0.19^{* * *} *$ leverage $j+\varepsilon j^{23}$

The F-statistic is highly significant and the $\mathrm{R}^{2}$ is 17.2 per cent. The regression indicates that there is a significant relationship between a sector's use of debt capital and its corporate tax payments. ${ }^{23}$ The result suggests that a sector by increasing its leverage from 45 per cent to 65 per cent can decrease its corporate tax payments measured as the tax to ebit ratio (tax/ebit) by four per centage points from 21.5 per cent to 17.7 per cent.

Summing up, the results presented in this section support the findings by, among others, Sørensen (2010) or Graham (2000) who suggest that there are differences in the effective tax rate that different firms face on their comparable incomes.

\section{Conclusion}

Standard literature suggests that the typical corporate tax system discriminates against equity financed investments. Interest costs are fully deductible while the costs associated with equity finance are not. Given that sectors differ with respect to their utilization of tangible assets that can be used to secure loans their ability to use debt finance varies. Consequently, sectors can be expected to differ with respect to how much of their income, ie calculated as ebit is to be paid as corporate income taxes. The differences are strongly related to a sector's use of debt capital. We find support for this central result from the literature on the corporate taxation. The data presented in this paper allows for

23 The methodology used in this paper does not differentiate between causality and correlation. One way to distinguish between the two would be to use Granger causality tests (Enders, 2004). Examples for such tests can be found in Lohse et al. (2014). 
a simple calculation indicating that the revenue effect of corporate interest rate deductions amount to approximately 6 per centage points. If one would abolish all interest rate deductions in the corporate sector the corporate income tax could be cut by 6 per centage points without losing any revenue in static terms. This finding is in line with the suggestions presented in the proposal presented by the Swedish Committee on Corporate Income Taxation. De Mooij and Devreux (2011) analyze the effect that such a reform would have for Sweden. They find that such a reform, introduced unilaterally would be beneficial for Sweden. However, while such a reform might be feasible in theory, it is beyond the scope of this paper to investigate if such a reform would be desirable 


\section{References}

Agell, Jonas, Englund, Peter and Södersten, Jan (1998). Incentives and Redistribution in The Welfare State. The Swedish Tax Reform. London: MacMillan Press.

Almeida, Heitor, and Thomas Philippon (2007). The risk-adjusted cost of financial distress. The Journal of Finance, 62: 2557-2586.

Andersson, Krister, Peter Ericson and Johan Fall (2013). European corporate tax policy andfinancial structure of corporations- with special reference to Sweden, Discussion paper for the 15th Annual European Conference, Swedish Network for European Studies in Economics and Business

Berg, C.J. Hansen and P. Sehlin (2004). The financial accelerator and corporate investment, Economic Review, 2: pp. 23-46.

Bernanke, B., M. Gertler och S. Gilchrist (1996), The Financial Accelerator and the Flight to Quality", Review of Economics and Statistics, 78, 1-15.

Bernanke, B., M. Gertler och S. Gilchrist (1999), “The Financial Accelerator in a Quantitative Business Cycle Framework", i Taylor, J. B. och M. Woodford (red.), Handbook of Macroeconomics, vol. 1(3), Amsterdam: North-Holland.

Bodie, Zvi and Robert Merton (2000). Finance.- Prentice Hall. Upper Saddle River, NJ, 2000.

Brown, J.R., Martinsson, G., \& Petersen, B. C. (2012). Do financing constraints matter for R\&D? European Economic Review, 56: 1512-1529.

Budgetpropositionen (2013). Budgetpropositionen 2012/13.

Diamond, Peter A., and James A. Mirrlees (1971). Optimal taxation and public production I: Production efficiency. American Economic Review: 8-27.

EU (2011 )Proposal for a Council Directive on a Common Consolidated Corporate Tax Base (CCCTB), SEC (2011) 315 final.

Enders, Walter (2004). Applied Econometric Time Series. 2nd edition. Holboken: Wiley.

Eriksson, Rickard and Peter Höglund (2013), General Economic Report, Taxation of the financial sector, Nordic Tax Journal 1, 49-67.

FSK (2014) Summaries of the proposal from the Swedish Committee on Corporate Taxationhttp://www.regeringen.se/content/1/c6/24/22/09/23b369ae.pdf

Graham, John (2000). "How big are the tax benefits of debt?." The Journal of Finance 55: 1901-1941.

Johansson, A., C. Heady, J. Arnold, B. Brys and L. Vartia (2008), “Tax and Economic Growth", OECD Economics Department Working Papers, No. 620, OECD, Paris

Kleist, David (2014) Corporate Tax in Sweden, Nordic Tax Journal. This volume

King, Mervyn, A. and Don Fullerton (1984) The taxation of income from capital: "A comparative study of the United States, the United Kingdom, Sweden, and Germany". NBER Books (1984).

Lee, Young, and Roger H. Gordon. "Tax structure and economic growth." Journal of public economics 89.5 (2005): 1027-1043.

Lindhe, Tobias, Jan Södersten, and Ann Öberg. "Economic effects of taxing different organizational forms under the Nordic dual income tax." International Tax and Public Finance 11.4 (2004): 469-485.

Lodin, Sven-Olof (2011). The making of tax law : The development of the Swedish tax system. 
Lohse, Tim, Pascalau, Razvan and Thomann, Christian (2014). Public Enforcement of Securities Market Rules: Resource-based evidence from the Securities Exchange Commission, Journal of Economic Behavior and Organization (forthcoming), http://dx.doi.org/10.1016/j.jebo.2014.06.010.

De Mooij, R.A., and Devereux, M. P. (2011). An applied analysis of ACE and CBIT reforms in the EU. International Tax and Public Finance, 18(1), 93-120.

Södersten, Jan (2014). Bolagsbeskattningens incitamentseffekter, Bilaga till Företagsskattekommitténs betänkande.

Sørensen, P.B. (2008). The taxation of business income in Sweden. Report prepared for the Swedish Ministry of Finance.

Sørensen, P.B. (2010). Swedish tax policy: Recent trends and future challenges. Finansdepartementet, Regeringskansliet.

OECD(2010), Tax Policy and Economic Growth,OECD Tax Policy Studies, No 20

OECD (2013), Addressing Base Erosion and Profit Shifting, Paris.

Skatteverket (2012), Delrapport - Skatteplanering med ränteavdrag i företag inom välfärdssektorn,

http://www.skatteverket.se/download/18.71004e4c133e23bf6db800076711/ 1335443101450/rapport20120427-+Skatteplanering+med+r\%C3\% A4nteavdrag.pdf

Wahlberg, Katrin (2012) Företagsbeskattning, Business taxation, Skatter i Sverige 2012, Skattestatistisk Årsbok,www.skatteverket.se/download/ 18.2b543913a42158acf800016970/1354883531590/15215.pdf

\section{Christian Thomann}

